\title{
Research on Lis Pendens in Private International
} Law

\author{
Baozhou Zhou \\ Istituto Italo-Cinese, Zhongnan University of Economics and Law, Wuhan, Hubei province, China
}

\begin{abstract}
Litigation concurrence, or parallel proceedings, is an essential issue in the international civil procedure law and judicial practice. It is a direct result of the division of national jurisdiction legislation at the international level. In order to avoid wasting judicial resources, the development of private international law has led to a move towards refinement and harmonisation of the provisions on parallel proceedings in national and international treaties. Lis pendens is a settlement of parallel proceedings and plays an important role in private international law.
\end{abstract}

Keywords: Lis Pendens, Parallel proceedings, Judicial discretion, Forum Non-Conveniens.

\section{Introduction}

Because of the differences in the legal system and judicial system of various countries, the existence of parallel litigation is reasonable, but we also have to realize the waste of judicial resources and the referee problem such as the difficulty of execution[1]. Therefore, under the international judicial coordination, states have formulated specific regulation means to avoid a variety of disadvantages caused by parallel litigation, such as Doctrine of Forum Non-Conveniens, the rules of res judicata, the selection method. Civil law countries avoid the waste of judicial resources by establishing Lis Pendens. This paper introduces the application of Lis Pendens in Germany, France, Brussels Regulation, and applies the comparative law method to draw on the provisions of foreign laws and international law, and puts forward some suggestions in combination with legislative practice in China.

\section{Lis Pendens in Civil Law Countries}

Lis pendens is a norm used to regulate international parallel litigation in the mainland legal system country and Brussels Regulation. Civil law is also called the written law system, and judges in civil law countries have limited discretion and must comply with the statute law. Two civil law system countries, Germany and France, ask judges to give up their jurisdiction in the case of strict legal refusal. Lis Pendens has a long history in the civil law system, which is consistent with the legal predictability and restricts the judge's judicial discretion.

Along with developing the EU regional treaties, Lis Pendens has been further enriched. The appropriate field has expanded to the British common law countries, compared to the Doctrine of Forum Non-Conveniens more long-term development prospects. Nevertheless, Lis Pendens was not as faultless. It is likely to lead to "litigation competition" between the parties and bring inconvenience to the court's jurisdiction, which requires inapplicable to its further improvement. Analysis of the advantages and disadvantages of Lis Pendens of the civil law system is of great significance to improve parallel litigation legislation in China.
The civil law system is established based on statute law. The judge's judicial discretion is limited, which the law leaves little room for the judge to change in essence. Once it is concluded based on logical reasoning that the court has jurisdiction by law, the court must exercise jurisdiction and judge only explains and enforces the law.

\subsection{Lis Pendens in Germany}

According to Lis Pendens, Germany makes the regulation for international parallel proceedings. "German civil procedural law" the 261th as prescribed in paragraph 3, "the judge will not accept the second lawsuit, when (1) have the same parties and (2) the same litigation reasons." Once, for example, to meet the rejected issue's requirements Lis Pendens, Germany judges have no choice but to issue in writing on rejecting lawsuit. The Lis Pendens rules in Germany apply to international jurisdiction issues, but their application varies from country to country.

On the one hand, another country court is the court of the European Union member states. According to German law, a foreign judgement in front of the German Court of appeal will be recognized and enforced by a German court. German judge will apply the principle of Lis Pendens to dismiss the case. Nevertheless, whether foreign judgments can be admitted to perform is outside the scope of article 27 of the Brussels Regulation. So when another country is a member of the European Union, it must be governed by Article 27 of the German court, rather than considering whether it is eligible for enforcement in Germany[2].

On the other hand, another country is not a member of the European Union. The German court still applies to the foreign court's judgment, enough to enable the court to recognize and enforce German standards. In the same party, according to the same lawsuit before the court has been caused by a foreign court lawsuit, and the foreign judgment can be recognized and enforced by the German court, the judge would dismiss the lawsuit. At present, the development of Lis Pendens tends to change according to Lis Pendens ruling. According to German law, judgments applied by Lis Pendens often dismiss the action. 
Nevertheless, considering the uncontrollable factors, the act of dismissing the verdict should be restricted. To avoid the risk of delaying the statute of limitations due to the parties playing a "game of jurisdiction", German courts tend to apply to suspend the proceedings rather than dismissing the lawsuit. Therefore, the German court has the discretion of suspending or dismissing the lawsuit but cannot continue proceeding with the case.

German Code of Civil Procedure(ZPO) rules on the court without judicial discretion. Once the judge has jurisdiction, he must hear the case. German law excludes Doctrine of Forum Non-Conveniens, but not absolute, logic similar to the common law legal system exists in the international scope of the non-lawsuit procedure. For example, in chapter 47 of the German Civil Code the non-lawsuit procedure law the first paragraph--the German Code of Non-Contentious Proceeding, if the guardian's interests are better defended in another court, allowing the court to appoint a guardian for the capacity, and courts are given the discretion to determine whether a guardian of the most significant interest. Chapter 47, paragraph 2, gives the court discretion to transfer guardianship to other courts to other courts to protect the best interest. This mechanism is similar to the Doctrine of Forum Non-Conveniens, which is not publicly recognized in German law.

Nevertheless, in a small range, the court has a certain degree of discretion. This does not affect the entire German legal system. Germany jurisdiction rule derives from paragraph 1 , article 101 of the German constitution, provides that the jurisdiction law may not be changed to ensure jurisdiction's predictability.

\subsection{Lis Pendens in France}

In France, the legislative power is in the hands of the legislature, and judges only explain and apply the law. Therefore, when the law gives jurisdiction over the case to the court, the court cannot refuse it on the grounds of inconvenient or inappropriate[3]. This concept is deeply rooted in the French judicial system and explains that the Doctrine of Forum Non-Conveniens is not accepted. It is illegal for a French judge to refuse to conduct a trial within an appropriate jurisdiction. France New Code of Civil Procedure the 100th clause is Lis Pendens, which generates when the "same lawsuit" is initiated in two courts all have jurisdiction. "France New Code of Civil Procedure" (NCPC) only requests the same dispute, "German Code of Civil Procedure" put forward two criteria, the same parties and the same cause of action. In French law, however, it is generally understood as the same dispute involves the consistent parties, disputes and cause of action.

The theoretical controversy mainly exists in the cause of action, which constitutes controversial of fact and the rule of law. In practice, all the legal facts and legal elements are exposed until the trial has progressed to a certain degree. That is the judge to determine whether the parallel litigation until at a particular stage of the trial. Furthermore, the parties participate in such a suit unnecessary. French Lis Pendens practice is similar to Germany, in which judges must also consider whether the following foreign judgments are accepted and enforced in their country.

\section{Brussels Regulation}

\subsection{Lis Pendens in Brussels Regulation}

Article 27 provides that the same parties in the same suit reason to different court cases, the latter court should suspend jurisdiction until the first has acquired the jurisdiction. Once the first gets the jurisdiction, other courts must refuse. The former Brussels convention stipulated in article 21, the lawsuit involving the same parties for the same reason is initiated to different State Parties, the first court gets jurisdiction, and others should refuse[4].

Compared to the regulations in Germany and France, there is no difference in terms of the definition of parallel proceedings. They all consist of three elements: the cause of the action, the same party, and the same time. Only differ in terms of processing, the Brussels convention article 21 asks the later court to refuse the jurisdiction. However, article 27 of the Brussels Regulation requirements the later court suspends firstly and refuses after the first court's jurisdiction is determined. That makes two litigation connections closer in time, and avoids the phenomenon that the latter court gives up jurisdiction, while the former court refuses the jurisdiction. To ensure that disputes between parties are resolved promptly.

\subsection{The Priority of Lis Pendens}

Through Erich Gasser GmbH v. MISAT Srl (E. C. R 2003), the Court of Justice of the European Union (CJEU) has clearly made that article 27 Lis Pendens is superior to article 23 forum shopping by agreement terms. The case was brought by an Italian company MISAT in Rome Court, and the company asked the court to announce the suspension of the contract with Austria company Gasser because the contract was not agreed upon. Eight months later, the Austrian company sued in Austria court, demanding that the Italian company pay according to the lading bill. These two proceedings involving the same cause of action. Gasser emphasized that the contract contained an exclusive agreement choice court clause and selected the court in Austria. Simultaneously, the Gasser company believes litigation is redundant and groundless to delay in the Italian court, and Lis Pendens clauses in the Brussels Regulation should be ignored.

In some countries such as Britain, judges have always supported and encouraged agreement jurisdiction clauses in commercial practice. Nevertheless, the CJEU rejected two claims of Gasser. According to the CJEU, Lis Pendens has higher legal authority than the choice of court agreement. On international parallel proceedings, the latter court will never have more priority than the former court, even if the former is the chosen court.

Also, CJEU noticed an exception of Lis Pendens, when the 
latter court should have the exclusive jurisdiction according to article 22 of the Brussels Regulation, and the former court does not have exclusive jurisdiction, the former court should give up its jurisdiction.

\subsection{Doctrine of Forum Non-Conveniens is not accepted in Brussels Regulation}

The Brussels Convention was signed in 1968 for the first time. All of the countries in the European Economic Community are civil law countries. Naturally, the convention does not contain any Doctrine of Forum Non-Conveniens provisions. To avoid parallel litigation among member states, EEC established strict terms of the Lis Pendens, giving the former court jurisdiction. Britain and Ireland joined the European Economic Community in 1979, and they try to negotiate Doctrine of Forum Non Conveniens terms into the Brussels convention. Other European countries reject this because they think that the convention has selected the linked convenient court case and has listed in article 4 of the Brussels convention a ban list, banning the court of excessive jurisdiction. So there is no real need for the Doctrine of Forum Non Conveniens terms. The representatives of the UK and Ireland eventually accept by default[5].

To achieve mutual trust and maintain EU justice, the European Union takes the strict Lis Pendens. Lis Pendens of Brussels Regulation is in a critical position in the EU council. During the unification movement of private international law, Lis Pendens plays a pivotal role.

\section{Lis Pendens in China}

\subsection{Article 533 of Interpretation of Supreme People's Court on the Application of the Civil Procedure Law of the People's Republic of China}

Article 533 of the Interpretation of the Civil Procedure Law of the People's Republic of China(ICPL) establishes the legal basis for recognizing judgment and examining litigation's concurrence at the execution stage. Where both a court in the People's Republic of China and a foreign court have jurisdiction over a case, and a party involved files a lawsuit with the foreign court while the other party files a lawsuit with the court in the People's Republic of China, the people's court may accept the case.

Once the Chinese court decides the dispute, the foreign judgment on the same dispute may not be recognized and enforced in China, unless China's international agreements have contracted or accessed to provide them otherwise. Combined with judicial practice, the main problems in Article 533 are summarized as follows.

Firstly, the regulation of duplicate parallel litigation is not clear. According to the first half of article 533, the fact that the same parties have sued in Foreign court for the same dispute cannot deny the Chinese courts' acceptance of the case. However, it only involves one party brings a suit in a foreign court and the other party brings a suit in a Chinese court. This is, it does not cover duplicate parallel litigation. In combination with Article 259 of the Civil Procedure Law, the foreign-related civil action shall be handled in accordance with other domestic provisions, which means that duplicate parallel proceedings should be prohibited according to article 247 of the ICPL. However, this interpretation is opposed to the scope of application of article 247 , those of duplicate prosecution between domestic courts. The scope of application of section 247 of the ICPL is limited to duplicate proceedings between domestic courts. After foreign courts have accepted a case, the party brings Chinse action, which does not violate the regulation prohibiting duplicate action. Anyway, there is no clear answer in the Civil Procedure Law and its judicial interpretation for the repeat parallel proceedings.

Secondly, the proceedings and judgments of China courts always take precedence over foreign courts, whether or not the foreign court that rendered the judgment precedes courts of China. The second half of Article 533 of the ICPL mainly includes two situations. Firstly, there are some conflicts between the judgments of the Chinese court and foreign courts. After the Chinese court makes the judgment, the foreign court requests the Chinese court to recognize and enforce the foreign court's action in the same case. Chinese court does not approve. In other words, in parallel proceedings, once our courts precede foreign courts, it shall not recognize and enforce a foreign court's judgment, whether or not the proceedings of a foreign court have commenced a Chinese court. This provision is likely to trigger a "race for a judgment" between the parties. Second, after a foreign court's judgments have been recognized and enforced by a Chinese court, the parties to the suit shall not be accepted by the people's court. This provision is intended to prevent Chinese courts from making judgments that conflict with foreign courts. However, if a foreign judgment has been made but have commenced applied for recognition and enforcement for Chinese court. The Chinese court may still accept the relevant case. Besides, it is difficult for Chinese courts to recognize and enforce foreign court judgment in our judicial practice. So it is highly likely that Chinese courts will accept the same case after a foreign court has decided.

\subsection{Article 54 of the Model Law of Private International Law}

The Model Law of Private International Law of the People's Republic of China (Model Law) 54 terms of parallel proceedings are the civil law principles of Lis Pendens. Article 54 provides that where a foreign court has rendered a judgment over an action between the same parties on the same subject matter or the action is pending before the court, a PRC court may not exercise its jurisdiction if it predicts the foreign judgment can be recognized in the PRC. It also provides that if the PRC court seizes the case first, or the legitimate interests of the parties cannot be safeguarded if the PRC court does not exercise the jurisdiction[6]. This is similar to Germany that the jurisdiction depends on whether it is recognized and enforced. 
As the court accepted the case-time criterion in model law 54, it was not specified. The Hague convention on international conference regards the time when the plaintiff submits the litigation materials to the court as the litigation time. France also uses the same criterion. In Germany, the time when the court serves the indictment to the defendant is the litigation time. This paper thinks that it is more appropriate to take the court's decision to file a case as the judgment standard in combination with the practice of civil procedure law in China.

\section{Conclusion}

There is no clear definition of international parallel litigation in Chinese law. The academic and judicial circles have not reached an agreement on this. The definition is the foundation of solving the difficult problem of international parallel litigation. It can be seen from various countries' legal practices and international treaties that the criterion for judging parallel proceedings has been gradually clarified. According to the Brussels Regulation of and other international conventions, the judgment of international parallel proceedings needs to meet three conditions: the same parties, the same causes of action, and the concurrent proceedings. China can also refer to this standard to clearly define the concept of parallel litigation. Based on article 54 of the existing Model Law in China, the definition of parallel litigation in China can be defined as litigation between the same parties for the same object of action in different national courts at the same time. It includes the same litigant, the same object of action, and the three parts of simultaneous action[7].

Besides, China is similar to the civil law system. Lis Pendens is more suitable for civil law countries. Domestic law in China strictly forbids parallel proceedings in the domestic civil procedure law to apply Lis Pendens to avoid parallel proceedings. However, because of the shortcomings of Lis Pendens, it is necessary to learn from the elements of the Doctrine of Forum Non-Conveniens to make up for them. Article 54 of the Model Law adopts the combination of Lis Pendens and the Doctrine of Forum Non-Conveniens, but the provisions are too general. Drawing on foreign countries' research results, we should pay attention to several problems in formulating the rules of parallel proceedings in China.

Draw lessons from Lis Pendens. From the legislative practice of Germany, France and some international treaties, although both countries apply Lis Pendens, there are differences in the time standard of "the court that accepts the action first."

According to the court's actual situation and needs in China, the definition of "the court that accepts the action first" should be clarified. Under the civil procedure law in China acceptance of a case by the court is regarded as the standard for the commencement of litigation. Therefore, the court that files a case first, namely, sues a court, is a former court.
[1] Son Tan Nguyen. The applicability of Res Judicata and Lis Pendens in World Trade Organisation dispute settlement[J]. Bond Law Review, 2019: 123-165.

[2] Matthias Weller. Choice of court agreements under Brussels Ia and under the Hague convention: coherences and clashes[J]. Journal of Private International Law, 2017, 13(1): 91-129.

[3] Alavi Hamed, Khamichonak Tatsiana. A Step Forward in the Harmonization of European Jurisdiction: Regulation Brussels I Recast[J]. Baltic Journal of Law \& Politics, 2015, 8(2): 95-113.

[4] Felix M Wilke. The impact of the Brussels I Recast on important "Brussels" case law $[\mathrm{J}]$. Journal of Private International Law,2015, 11(1): 128-142.

[5] Mukarrum Ahmed, Paul Beaumont. Exclusive choice of court agreements: some issues on the Hague Convention on choice of court agreements and its relationship with the Brussels I recast especially anti-suit injunctions, concurrent proceedings and the implications of BREXIT[J]. Journal of Private International Law, 2017, 13(2): 386-410.

[6] Xu Wei-gong. Comment on Forum Non Conveniens Article of Model Law of Private International Law [J]. Wuhan University Journal (Philosophy \& Social Sciences), 2004(03): 392-397.

[7] Quim Forner-Delaygua. Changes to jurisdiction based on exclusive jurisdiction agreements under the Brussels I Regulation Recast[J]. Journal of Private International Law, 2015, 11(3): 153-164.

\section{References}

